\section{BISTT gayrimenkul yatırım ortaklıkları endeksi ile konut fiyat endeksi, faiz oranı ve enflasyon ilişkisi: ARDL sınır testi yaklaşımı}

\section{The relationship between BIST real estate investment trusts index and house price index, interest rate and inflation: ARDL bounds testing approach}

\author{
Rifat Karakuş 1 \\ Sezer Öksüz²
}

Öz

${ }^{1}$ Dr. Öğr. Üyesi, Çankırı Karatekin Üniversitesi, İ̈BF, Finans ve Bankacilık Bölümü, Çankırı, Türkiye, rifatkarakus@karatekin.edu.tr

ORCID: 0000-0003-3580-5207

2 Dr. Öğr. Üyesi, Çankırı Karatekin Üniversitesi, MYO, Finans-Bankacilık ve Sigortacılık Bölümü, Çankırı, Türkiye, sezeroksuz@karatekin.edu.tr

ORCID: 0000-0002-9567-8142

Sorumlu Yazar/Corresponding Author:

Rıfat Karakuş,

Çankırı Karatekin Üniversitesi, Çankırı Türkiye, rifatkarakus@karatekin.edu.tr

Başvuru/Submitted: 25/04/2021

Revizyon/Revised: 13/06/2021

Kabul/Accepted: 15/06/2021

Yayın/Online Published: 25/06/2021

Atıf/Citation: Karakuş, R., \& Öksüz, S., BIST gayrimenkul yatırım ortaklıkları endeksi ile konut fiyat endeksi, faiz oranı ve enflasyon ilişkisi: ARDL sınır testi yaklaşımı, bmij (2021) 9 (2): 751-764, doi: https://doi.org/10.15295/bmij.v9i2.1825
Bu çalışmanın amacı, BİST Gayrimenkul Yatırım Ortaklıkları Endeksi ile konut fiyat endeksi, faiz oranı ve enflasyon ilişkisinin araştırılmasıdır. Çalışmada Ocak 2010-Aralık 2020 dönemi için BİST Gayrimenkul Yatırım Ortaklıkları Endeksi ile konut fiyat endeksi, kira tüketici fiyat endeksi ve konut kredisi faiz oranlarının aylık verileri kullanılarak ARDL Sınır Testi ile eşbütünleşme ilişkisi incelenmiş, uzun ve kısa dönem katsayıları tahmin edilmiştir. Analizler sonucunda BísT Gayrimenkul Yatırım Ortaklıkları Endeksi ile konut fiyat endeksi, kira tüketici fiyat endeksi ve konut kredisi faiz oranları arasında eşbütünleşme bulunduğu; uzun dönemde konut fiyat endeksindeki artışın BíST Gayrimenkul Yatırım Ortaklıkları Endeksini artırdığı, kira tüketici fiyat endeksi ve konut kredisi faiz oranlarındaki artışın ise BISTT Gayrimenkul Yatırım Ortaklıkları Endeksini düşürdüğü belirlenmiştir.

Anahtar Kelimeler: BİST Gayrimenkul Yatırım Ortaklıkları Endeksi, Konut Fiyat Endeksi, Faiz Oranı, Enflasyon, ARDL Sinir Testi

Jel Kodları: G10, G11, E44

\begin{abstract}
This study aims to investigate the relationship between BIST Real Estate Investment Trusts Index and the housing price index, interest rate, and inflation. In the study, the cointegration relationship is examined with the ARDL bounds testing approach using the monthly data of BIST Real Estate Investment Trusts Index, the house price index, rental consumer price index and house loan interest rates for the period January 2010-December 2020 and the long and short-term coefficients are estimated. As a result of the analysis, there is cointegration between BIST Real Estate Investment Trusts Index and the house price index, the rental consumer price index and the house loan interest rates; in the long term, the increase in the house price index increases BIST Real Estate Investment Trusts Index, however the increase in the rental consumer price index and house loan interest rates decreases BIST Real Estate Investment Trusts Index.
\end{abstract}

Keywords: BIST Real Estate Investment Trusts Index, House Price Index, Interest Rate, Inflation, ARDL Bounds Testing Approach

Jel Codes: G10, G11, E44 


\section{Extended Abstract}

\section{The relationship between BIST real estate investment trusts index and house price index, interest rate and inflation: ARDL bounds testing approach}

\section{Literature}

\section{Research subject}

This study aims to investigate the relationship between BIST Real Estate Investment Trusts Index and the housing price index, interest rate, and inflation.

\section{Research purpose and importance}

Investors and managers need to determine the factors that affect the stock value. Determining the factors affecting the share value of real estate investment trusts, which have an essential role in capital markets with their market values, asset sizes and transaction volumes, will also benefit practitioners. Findings will contain important information that practitioners can use (investors, managers, etc.) in decision processes.

\section{Contribution of the article to the literature}

Studies examining the effect of macroeconomic factors on REIT's stock value, stock return or REIT indices (Chen and Tzang, 1988; Ewing and Payne, 2005; Nishigaki, 2007; Hoesli and Oikarinen, 2012; Kırdök, 2012; Zügül and Şahin, 2015; Fang, Chang, Lee and Chen, 2016; Kandır and Özhan, 2018; Özkan, 2018; Afşar and Karpuz, 2019; Arora, Killins and Gangineni, 2019; Khan and Siddiqui, 2019; Cohen and Burinskas, 2020; Olanrele et al., 2021) exist in the literature. When the studies in the literature are examined, it is seen that different findings are reached regarding the effect of the house price index, interest rates and inflation rates on REITs stock prices and returns for different markets. For Turkey, studies examining the factors that affect the returns and stock prices of REITs are limited. This study will contribute to the existing literature by examining the effect of the house price index, interest rate and inflation rate on the BIST Real Estate Investment Trusts Index using a current data set and a different method from studies in the literature about Turkey.

\section{Design and method}

\section{Research type}

Quantitative methods are used in this study. The cointegration between the house price index, interest rate, inflation rate and BIST Real Estate Investment Trusts Index and the effect of the house price index, interest rate and inflation rate on the BIST Real Estate Investment Trusts Index are investigated by econometric models.

\section{Research problems}

Whether there is cointegration between the house price index, interest rate, inflation rate and BIST Real Estate Investment Trusts Index or not and whether the house price index, interest rate and inflation rate affect BIST Real Estate Investment Trusts Index or not are investigated in the study.

\section{Data collection method}

In the study, BIST Real Estate Investment Trusts Index, house price index, house loan interest rates, and rent consumer price index are included in the data set and the data of the relevant variables are used monthly for January 2010-December 2020. BIST Real Estate Investment Trusts Index data are obtained from Borsa Istanbul database; House Consumer Price Index data are obtained from Turkey Statistical Institute database; Housing Price Index and the Housing Loan Interest Rate data are obtained from the Central Bank of the Republic of Turkey database.

\section{Quantitative/qualitative analysis}

To examine the cointegration between the house price index, interest rate, inflation rate and BIST Real Estate Investment Trusts Index and the effect of the house price index, interest rate and inflation rate on the BIST Real Estate Investment Trusts Index, the ARDL bounds testing approach is used. Firstly, unit root tests are applied to determine the stationary of series. Then by using the bounds testing approach, the cointegration is analyzed. Finally, long-term coefficients are estimated by the ARDL approach, and short-term coefficients are estimated with an error correction model.

\section{Research model}

The model is created such that BIST Real Estate Investment Trusts Index is a dependent variable, and the house price index, rental consumer price index, house loan interest rates are independent variables.

\section{Research hypotheses}

The hypotheses of the study are as below:

$\mathrm{H}_{1}$ : There is cointegration between the house price index, interest rate, inflation rate and BIST Real Estate Investment Trusts Index.

$\mathrm{H}_{2}$ : House price index has a statistically significant effect on BIST Real Estate Investment Trusts Index.

$\mathrm{H}_{3}$ : Rental consumer price index has a statistically significant effect on BIST Real Estate Investment Trusts Index.

$\mathrm{H}_{4}$ : House loan interest rates have a statistically significant effect on BIST Real Estate Investment Trusts Index.

\section{Findings and discussion}

\section{Findings as a result of analysis}

The findings show that the house price index positively affects the BIST Real Estate Investment Trusts Index. 1\% increase in the house price index in the long term provides an increase of $2.61 \%$ in the BIST Real Estate Investment Trusts Index. In the study, it 
is also determined that the increase in the rental consumer price index, which is among the particular consumer price index indicators, negatively affects the BIST Real Estate Investment Trusts Index, and a 1\% increase in the rental consumer price index decreases the BIST Real Estate Investment Trusts Index by 2.16\%. Another result in the study is that the increase in house loan interest rates negatively affects the BIST Real Estate Investment Trusts Index. One hundred basis points increase in TLdenominated house loan interest rates in the long run causes to decrease in BIST Real Estate Investment Trusts Index by $0.0058 \%$.

\section{Hypothesis test results}

It is determined that there is cointegration between the house price index, interest rate, inflation rate and BIST Real Estate Investment Trusts Index. House price index has a statistically significant and positive effect on BIST Real Estate Investment Trusts Index. Rental consumer price index and house loan interest rates have statistically significant and negative effect on BIST Real Estate Investment Trusts Index.

\section{Discussing the findings with the literature}

Although it was determined by Kandır and Özhan (2018) that the house price index did not have a significant effect on the BIST Real Estate Investment Trusts Index, a positive effect is found in this study in line with the expectations. This result is consistent with the result reached by Nishigaki (2007) for the US market. The results for the effect of inflation are consistent with the findings of studies using different inflation indicators instead of the rental consumer price index used such as Nishigaki (2007), Fang, Chang, Lee, and Chen (2016), Arora, Killins and Gangineni (2019) and Cohen and Burinskas (2020). The findings obtained are similar to the studies of Zügül and Şahin (2015), Fang, Chang, Lee and Chen (2016) and Khan and Siddiqui (2019), which determined the negative effect of interest on REIT share values.

\section{Conclusion, recommendation and limitations}

\section{Results of the article}

As a result of the study, there is cointegration between the house price index, interest rate, inflation rate and BIST Real Estate Investment Trusts Index. In the long-term, an increase in the house price index results in an increase in BIST Real Estate Investment Trusts Index However, an increase in interest rate and inflation rate cause a decrease in BIST Real Estate Investment Trusts Index.

\section{Suggestions based on results}

The findings have important implications for investors. In investments to be made in REIT stocks, the house price index, interest rates and inflation rates should be carefully evaluated by investors. Making decisions by investors, considering that REIT shares value will increase in periods when an increase in house prices is expected and that REIT stock values will be negatively affected in periods where an increase in interest rates and inflation rates is expected, will positively affect the portfolio returns of investors. Managers, who focus financially on maximizing shareholder value and want to be effective in achieving their financial goals, will develop policies to prevent the share value of REITs from being affected by the increase in interest rates and inflation rate and the decrease in house prices.

\section{Limitations of the article}

The main limitation of this study is that it focuses on the effects of certain variables. Including firm-specific factors in the analysis or categorizing firms according to their specific characteristics and comparing analysis results may contribute to the literature. Future studies may include firm-specific factors in the research model. 


\section{Giriş}

Gayrimenkul yatırım ortaklığı (GYO), Gayrimenkul Yatırım Ortaklıklarına İlişkin Esaslar Tebliği'nde, "belirlenmiş usul ve esaslar dâhilinde, gayrimenkuller, gayrimenkul projeleri, gayrimenkule dayalı haklar, altyapı yatırım ve hizmetleri, sermaye piyasası araçları, Takasbank para piyasası ve ters repo işlemleri, Türk Lirası cinsinden vadeli mevduat veya katılma hesabı, yabancı para cinsinden vadeli ve vadesiz mevduat veya özel cari ve katılma hesapları ile iştirakler ve Kurulca belirlenecek diğer varlık ve haklardan oluşan portföyü işletmek amacıyla paylarını ihraç etmek üzere kurulan" sermaye piyasası kurumu olarak tanımlanmıştır. Diğer kolektif yatırım kuruluşlarında olduğu gibi riskin dağıtılması ve profesyonel yönetim ilkeleri doğrultusunda özellikle gayrimenkul, gayrimenkul projeleri ve gayrimenkule dayalı sermaye piyasası araçlarına yatırım yapan GYO'lar dünyada ve Türkiye'de sermaye piyasalarında piyasa değeri, aktif büyüklük ve hacim olarak önemli bir yere sahiptirler.

ABD'de 2020 yılı itibariyle 191 GYO faaliyet göstermekte olup 980 milyar Euro toplam piyasa kapitalizasyonu ile dünyada ilk sırada yer almaktadır. Birleşik Krallık, Kanada ve Fransa GYO'ların piyasa kapitalizasyonunda dünyada önde gelen ülkeler olarak yer almaktadır.

Tablo 1. Seçilmiş Ülkelerde 2020 Yılı İtibariyle GYO'lar

\begin{tabular}{|c|c|c|}
\hline Ülke & GYO Sayısı & $\begin{array}{c}\text { Sektör Piyasa Kapitalizasyonu } \\
\text { (milyon Euro) }\end{array}$ \\
\hline Birleşik Krallık & 53 & 58.537 \\
\hline Almanya & 6 & 4.442 \\
\hline Fransa & 28 & 40.120 \\
\hline İspanya & 77 & 20.634 \\
\hline ABD & 191 & 980.842 \\
\hline Kanada & 45 & 46.318 \\
\hline Çin & 5 & 4.430 \\
\hline Japonya & 66 & 107.970 \\
\hline Güney Afrika & 31 & 8.699 \\
\hline
\end{tabular}

Kaynak: European Public Real Estate Association (ERPA), 2020

Tablo 2'de hisse senetleri Borsa İstanbul' da işlem gören GYO'lara ilişkin temel değerler y1llar itibariyle sunulmuştur. Türkiye'de 2020 yllı sonunda 33 GYO faaliyette bulunmakta olup piyasa değerleri toplamı 7 milyar USD'nin üzerindedir. Türkiye'de borsaya kote şirketlerin toplam piyasa kapitalizasyonunun 2020 yılı için yaklaşık 185 milyar USD olduğu (World Bank, 2021) değerlendirildiğinde GYO'lar \%3,94 ile halka açık şirketler arasında önemli bir yere sahiptir. 94 milyar TL'nin üzerinde aktif toplam ile önemli bir varlık seviyesine ulaşan GYO'ların 2020 yılında Borsa İstanbul' da işlem hacmi de 445 milyar TL'nin üzerindedir.

Tablo 2. Borsa İstanbul' da İşlem Gören GYO'lar

\begin{tabular}{|c|c|c|c|c|c|c|c|c|c|c|}
\hline & 2011 & 2012 & 2013 & 2014 & 2015 & 2016 & 2017 & 2018 & 2019 & 2020 \\
\hline $\begin{array}{l}\text { Borsa İstanbul'da İşlem } \\
\text { Gören GYO Sayıs1 } \\
\end{array}$ & 25 & 26 & 30 & 31 & 31 & 32 & 31 & 33 & 33 & 33 \\
\hline Halka Açıklık Oranı & $43 \%$ & $38 \%$ & $51 \%$ & $52 \%$ & $52 \%$ & $51 \%$ & $50 \%$ & $53 \%$ & $53 \%$ & $53 \%$ \\
\hline $\begin{array}{l}\text { Halka Açıklık Oranı (Fiili } \\
\text { Dolaşım) }\end{array}$ & $23 \%$ & $25 \%$ & $37 \%$ & $37 \%$ & $42 \%$ & $39 \%$ & $39 \%$ & $38 \%$ & $36 \%$ & $32 \%$ \\
\hline $\begin{array}{l}\text { Piyasa Değerleri (Milyon } \\
\text { TL) }\end{array}$ & 10.864 & 15.800 & 18.119 & 21.731 & 21.465 & 25.447 & 26.924 & 18.384 & 27.777 & 54.163 \\
\hline $\begin{array}{l}\text { Piyasa Değerleri (Milyon } \\
\text { USD) }\end{array}$ & 5.751 & 8.888 & 8.505 & 9.339 & 7.356 & 7.231 & 7.138 & 3.481 & 4.676 & 7.300 \\
\hline İşlem Hacmi (Milyon TL) & & 26.873 & 34.113 & 38.088 & 33.581 & 37.003 & 74.348 & 49.174 & 70.436 & 445.147 \\
\hline $\begin{array}{l}\text { Dağıtılan Temettü Tutarları } \\
\text { (Milyon TL) }\end{array}$ & 213 & 376 & 311 & 697 & 733 & 676 & 447 & 1.131 & 822 & 367 \\
\hline $\begin{array}{l}\text { Konsolide Olmayan Aktif } \\
\text { Toplamı (Milyon TL) }\end{array}$ & 20.770 & 24.086 & 37.572 & 42.059 & 52.530 & 60.602 & 67.161 & 79.414 & 86.227 & 94.881 \\
\hline
\end{tabular}

Gerek dünyada gerekse Türkiye'de sermaye piyasalarında önemli bir büyüklüğe sahip olan GYO'ların hisse performansları yöneticiler ve yatırımcılar açısından ciddi bir öneme sahiptir. GYO'ların hisse değerine ve hisse getirilerine etki eden faktörlerin belirlenmesi yöneticiler ve yatırımcılar için yol gösterici olacaktır. Bu çalışmanın amacı da konut fiyat endeksi, konut kredisi faiz oranları ve gerçek kira enflasyonu ile Türkiye'deki GYO'ların hisse değeri arasındaki ilişkinin belirlenmesidir. Bu amaç doğrultusunda çalışmanın ilerleyen bölümlerinde GYO'ların hisse performansına etki eden faktörleri araştıran çalışmalar özet şekilde sunulacak, veri seti ve yöntem açıklanarak elde edilen bulgular değerlendirilecektir. 


\section{Literatür taraması}

GYO'ların sermaye piyasaları içerisindeki önemli yeri, akademik yazında da birçok çalışmaya konu edilmelerini sağlamıştır. Türkiye piyasası için akademik çalışmaların genellikle GYO'ların etkinlik analizine (Türkmen, 2011; Aytekin ve Kahraman, 2015; Karakaya, 2017; Münyas,2018) ve GYO'lara özgü faktörlerin performanslarına etkisine (Şahin, 2014; Çelik ve Manan, 2018; Çelik ve Arslanlı, 2020) odaklandığı görülmektedir. Enflasyon oranı, faiz oranları, konut fiyat endeksi gibi makroekonomik faktörlerin GYO'ların hisse değerine veya getirisini inceleyen çalışmaların ise Türkiye için sınırlı olduğu görülmektedir. Makroekonomik faktörlerin GYO'ların hisse senetleri değeri, hisse senedi getirisi veya GYO endeksleri üzerindeki etkisini inceleyen çalışmalar Tablo 3' de özet olarak sunulmuştur.

Tablo 3. Literatür Taraması

\begin{tabular}{|c|c|c|c|}
\hline Yazar(lar) & Veri Seti & Yöntem & Sonuclar \\
\hline $\begin{array}{l}\text { Chen ve } \\
\text { Tzang (1988) }\end{array}$ & $\begin{array}{l}\text { 1973-1985 dönemi için ABD } \\
\text { borsalarında işlem gören } 32 \\
\text { gayrimenkul yatırım ortaklığı ve } 22 \\
\text { mortgage gayrimenkul yatırım } \\
\text { ortaklığının aylık getirileri ile aylık } \\
\text { faiz oranları ve enflasyon oranları }\end{array}$ & $\begin{array}{l}\text { Regresyon } \\
\text { Analizi }\end{array}$ & $\begin{array}{l}\text { GYO'ların ve mortgage GYO'ların 1973-1979 dönemi } \\
\text { için uzun vadeli faiz oranlarındaki değişikliklere } \\
\text { duyarlı oldukları, ancak 1980-1985 döneminde hem } \\
\text { kısa vadeli hem de uzun vadeli faiz oranlarındaki } \\
\text { değişikliklere duyarlı oldukları, GYO ve mortgage } \\
\text { GYO'ların faize duyarlılığının kaynaklarının farklı } \\
\text { olduğu, GYO'ların beklenen enflasyondaki } \\
\text { değişikliklere duyarlı olduğu, mortgage GYO'ların } \\
\text { hem beklenen enflasyondaki değişikliklere hem de } \\
\text { reel orandaki değişikliklere duyarlı olduğu } \\
\text { belirlenmiştir. }\end{array}$ \\
\hline $\begin{array}{l}\text { Ewing ve } \\
\text { Payne (2005) }\end{array}$ & $\begin{array}{l}\text { Ocak 1980-Eylül } 2000 \text { dönemi için } \\
\text { ABD'de halka açık tüm GYO'ları } \\
\text { kapsayan NAREIT endeksi getirileri } \\
\text { ile ekonomik büyüme, para } \\
\text { politikass temerrüt risk primi ve }\end{array}$ & $\begin{array}{l}\text { VAR modeli ve } \\
\text { Etki-Tepki } \\
\text { Analizi }\end{array}$ & $\begin{array}{l}\text { Ekonomik büyüme, para politikası ve enflasyon } \\
\text { şokları GYO'lar için beklenen getiriden daha düşük } \\
\text { bir getiriye neden olurken enflasyondaki şoklar daha } \\
\text { yüksek getirilere neden olmaktadır. }\end{array}$ \\
\hline
\end{tabular}
politikasi, veriler

\begin{tabular}{ll}
\hline Nishigaki & Ocak1980 ile Kasım 2006 dönemi için \\
(2007) & ABD'de GYO endeksi ile konut \\
& fiyatları, borsa endeksi, 10 yıllık faiz \\
& oranları ve tüketici fiyat endeksine \\
& ilişkin aylık veriler
\end{tabular}

JohansenJuselius Eşbütünleşme Testi ve Vektör Hata Düzeltme Modeli

\begin{tabular}{ll}
\hline Hoesli ve & ABD ve Avustralya için 1994-2010 \\
Oikarinen & dönemi ve Birleşik Krallı için 1991- \\
(2012) & 2010 dönemine ait GYO endeksleri \\
& ile gayrimenkul fiyatlarının üçer \\
& aylık verileri ile kontrol değişkenler \\
& olarak borsa endeksleri, ekonomik \\
& büyüme, ekonomik güven, kısa \\
& dönemli faiz oranları, faiz \\
& oranlarının vade yapısı, temerrüt risk \\
& primi ve enflasyon oranı
\end{tabular}

\begin{tabular}{ll}
\hline Kırdök & Ocak 2000 - Aralık 2011 dönemi için \\
(2012) & Türkiye'deki gayrimenkul yatrım \\
& ortaklıkları getirileri ile piyasa \\
& getirisi, sanayi üretimi, enflasyon, \\
& beklenmedik enflasyon, faiz oran, \\
& vade primi ve iflas risk primi, \\
& büyüklük ve defter değeri/piyasa \\
& değerine ilişkin aylık veriler
\end{tabular}

\begin{tabular}{lll}
\hline Zügül ve & Ocak 2007- Aralık 2012 dönemi için \\
Şahin (2015) & aylı gayrimenkul yatırım \\
& $\begin{array}{l}\text { ortaklıkları (GYO) endeksi getirileri } \\
\text { ile enflasyon oranı (TÜFE) ve } \\
\text { mevduat faiz oranı }\end{array}$
\end{tabular}

Fang,
Chang, Lee
ve Chen
$(2016)$

Mart 2008 - Temmuz 2012 dönemi için Japonya, Çin ve Singapur gayrimenkul yatırım ortaklıkları (GYO) endeksleri ile ilgili ülkelerin borsa endeksleri, faiz oranları ve

\section{Eşbütünleşme} Analizi, Öngörü Hatası Varyans Ayrıştırmasi, Etki-Tepki Analizi

\begin{abstract}
Uzun dönemde, konut fiyatlarındaki artışı GYO endeksini pozitif yönde etkilediği, enflasyon oranındaki artışın ise GYO endeksini negatif yönde etkilediği belirlenirken diğer değişkenlerin etkisi istatistiksel olarak açıklanamamıştır.
\end{abstract}

$A B D$ ve Birleşik Krallık için GYO endeksleri ile gayrimenkul fiyatlarının uzun dönemde ilişkili olduğu, gayrimenkul fiyatlarının uzun vadeli öngörü hatası varyansının büyük bir kısmının GYO getiri şokları ile açıklanabildiğini, öngörülebilirliğin GYO'lardan gayrimenkullere doğru olduğunu, uzun dönemde GYO'lar ile gayrimenkul fiyatları arasındaki benzerliğin GYO'lar ile borsa endeksleri arasındaki benzerlikten önemli ölçüde fazla olduğu belirlenmiştir. Avustralya için ise GYO endeksleri ile gayrimenkul fiyatları arasında güvenilir bir ilişki tespit edilememiştir.

\begin{tabular}{|c|c|}
\hline Sinırlandırılma & enflasyon, piyasa getirileri ve faiz \\
\hline miş Vektör & priminin GYO getirilerini \\
\hline Otoregresif & açıklamada önemli rol oynadığı, GMYO getirilerinin \\
\hline Model, & piyasa getirileri ve iflas risk primindeki beklenmedik \\
\hline Varyans & şoklara pozitif, gecelik faiz oranları ve vade \\
\hline Dağılımı & primindeki şoklara ise negatif yönde tepki verdiği \\
\hline Genelleştirilmiş & belirlenmiştir. \\
\hline Etki-Tepki & \\
\hline Fonksiyonları & \\
\hline Çoklu & Mevduat faiz oranı ile GYO endeks getirisi arasında \\
\hline Regresyon & anlamlı ve negatif yönlü bir ilişki olduğu belirlenirken \\
\hline Analizi & $\begin{array}{l}\text { enflasyon oranı ile GYO endeks getirisi arasında } \\
\text { anlamlı bir ilişki olmadığı tespit edilmiştir. }\end{array}$ \\
\hline
\end{tabular}

ARDL Sınır Testi Japonya, Singapur ve Çin için borsa endeksindeki ve Toda- artışın GYO endeksini pozitif yönde, enflasyon Yamamoto oranındaki artışın ise negatif yönde etkilediği Nedensellik belirlenmiştir. Faiz oranlarındaki artışın da Japonya Testi ve Singapur için GYO endeksini negatif yönde etkilediği tespit edilmiştir. Ayrıca Japonya ve 


\begin{tabular}{|c|c|c|c|}
\hline & $\begin{array}{l}\text { enflasyon oranlarına ilişkin aylık } \\
\text { veriler }\end{array}$ & & $\begin{array}{l}\text { Singapur için enflasyon oranından GYO endeksine ve } \\
\text { Singapur için borsa endeksinden GYO endeksine } \\
\text { doğru nedensellik olduğu sonucuna varılmıştır. }\end{array}$ \\
\hline $\begin{array}{l}\text { Kandır } \\
\text { Özhan } \\
(2018)\end{array}$ & $\begin{array}{l}\text { 2010:2 -2018:6 dönemleri arasinda } \\
\text { BIST'de kayitlı 16 GYO'nun aylık pay } \\
\text { getirileri ile BİST-100 endeksi ve } \\
\text { Konut Fiyat Endeksi }\end{array}$ & $\begin{array}{l}\text { Basit Regresyon } \\
\text { Modeli }\end{array}$ & $\begin{array}{l}\text { BİST-100 endeksindeki artışın GYO getirilerini pozitif } \\
\text { etkilediği belirlenirken, Konut Fiyat Endeksinin GYO } \\
\text { getirileri üzerinde etkisi bulunmadığı belirlenmiştir. }\end{array}$ \\
\hline $\begin{array}{l}\text { Özkan } \\
(2018)\end{array}$ & $\begin{array}{l}\text { Ocak 2005- Aralık } 2017 \text { dönemi için } \\
\text { BiST GYO Endeksi ile BİST-100 } \\
\text { endeksi, enflasyon oranı, sanayi } \\
\text { üretimi, döviz kuru, faiz oranı ve } \\
\text { tüketici güven endeksine ilişkin aylık } \\
\text { veriler }\end{array}$ & $\begin{array}{l}\text { Johansen } \\
\text { Eşbütünleşme } \\
\text { Testi, Vektör } \\
\text { Hata Düzeltme } \\
\text { Modeli ve } \\
\text { Granger } \\
\text { Nedensellik } \\
\text { Testi }\end{array}$ & $\begin{array}{l}\text { BíST-100 endeksi, sanayi üretimi, döviz kuru ve } \\
\text { tüketici güven endeksinden BİST GYO endeksine } \\
\text { doğru tek yönlü ve enflasyon oranı ile BİST GYO } \\
\text { endeksi arasında çift yönlü nedensellik ilişkisi } \\
\text { bulunduğu sonucuna varılmıştır. }\end{array}$ \\
\hline $\begin{array}{l}\text { Afşar } \\
\text { Karpuz } \\
(2019)\end{array}$ & $\begin{array}{l}2000-2017 \text { dönemi için BIST GYO } \\
\text { endeksi ile BIST100 endeksi, } \\
\text { ekonomik büyüme (reel GSYİH), } \\
\text { mevduat faizi oranı ve enflasyon } \\
\text { oranına (TÜFE) ilişkin çeyreklik } \\
\text { veriler }\end{array}$ & $\begin{array}{l}\text { Granger } \\
\text { Nedensellik } \\
\text { Testi }\end{array}$ & $\begin{array}{l}\text { Mevduat faiz oranlarından BİST GYO endeksine } \\
\text { doğru tek yönlü bir nedensellik bulunurken, BİST } \\
\text { GYO endeksinden ise ekonomik büyüme ve enflasyon } \\
\text { oranına doğru tek yönlü bir nedensellik ilişkisi } \\
\text { olduğu bulunmuştur. }\end{array}$ \\
\hline $\begin{array}{l}\text { Arora, } \\
\text { Killins ve } \\
\text { Gangineni } \\
(2019)\end{array}$ & $\begin{array}{l}2004 \text { - } 2013 \text { dönemi için Singapur } \\
\text { gayrimenkul yatırım ortaklıkları } \\
\text { getirileri ile GYO'lara özgü faktörler } \\
\text { ve GSYİH, enflasyon oranı, para arzı, } \\
\text { faiz oranı ve döviz kuruna ilişkin } \\
\text { çeyreklik veriler }\end{array}$ & Panel veri analizi & $\begin{array}{l}\text { Çalışmada kurulan ve sadece makroekonomik } \\
\text { faktörlerin yer aldığı modeller sonucunda enflasyon } \\
\text { ve dolar kurunun GYO getirilerini negatif yönde } \\
\text { etkilediği belirlenirken diğger değişkenlerinin etkisinin } \\
\text { modellere göre farklılaştığı sonucuna varılmıştır. }\end{array}$ \\
\hline $\begin{array}{l}\text { Khan ve } \\
\text { Siddiqui } \\
\text { (2019) }\end{array}$ & $\begin{array}{l}\text { 2009-2018 dönemi için Pakistan, } \\
\text { Malezya, Tayland, Singapur ve Hong } \\
\text { Kong'dan } 21 \text { GYO'nun net varlık } \\
\text { değerleri ile temettü verimleri, net } \\
\text { gelirleri, büyüklükleri ve ilgili } \\
\text { ülkelerin borsa endeksleri, faiz } \\
\text { oranları ve enflasyon oranları }\end{array}$ & $\begin{array}{l}\text { Panel Regresyon } \\
\text { Analizi }\end{array}$ & $\begin{array}{l}\text { GYO'ların temettü verimleri, net gelirleri, } \\
\text { büyüklükleri ile bulundukları ülkenin borsa } \\
\text { endeksleri ve enflasyon oranlarının GYO'ların net } \\
\text { varlı değerlerini pozitif yönde etkilediği, } \\
\text { bulundukları ülkedeki faiz oranının ise GYO'ların net } \\
\text { varlı değerlerini negatif yönde etkilediği } \\
\text { belirlenmiştir. }\end{array}$ \\
\hline $\begin{array}{l}\text { Cohen ve } \\
\text { Burinskas } \\
(2020)\end{array}$ & $\begin{array}{l}2006-2019 \text { dönemi için gayrimenkul } \\
\text { şirketleri ve gayrimenkul yatırım } \\
\text { ortaklıklarını içeren FTSE EPRA } \\
\text { Nareit Developed Europe Endeksi ile } \\
\begin{array}{ll}\text { Avrupa bölgesi için } 18 \\
\text { makroekonomik değişkene ait } \\
\text { çeyreklik veriler }\end{array} \\
\end{array}$ & $\begin{array}{l}\text { Dinamik } \\
\text { Doğrusal Model }\end{array}$ & $\begin{array}{l}\text { İnşaat hacmi, üretici fiyat endeksi ve reel efektif Euro } \\
\text { kuru ile FTSE EPRA Nareit Developed Europe } \\
\text { Endeksi arasında negatif yönlü, Avrupa Merkez } \\
\text { Bankası' nın genişlemeci para politikası ile pozitif } \\
\text { yönlü ilişki bulunduğu sonucuna varılmıştır. }\end{array}$ \\
\hline $\begin{array}{l}\text { Olanrele ve } \\
\text { diğerleri } \\
\text { (2021). }\end{array}$ & $\begin{array}{l}2008 \text { - } 2017 \text { dönemi için Nijerya } \\
\text { gayrimenkul yatırım ortaklıklarının } \\
\text { temettü getirileri ile enflasyon, döviz } \\
\text { kuru, faiz oranı, piyasa } \\
\text { kapitalizasyonu ve tüm hisseler } \\
\text { endeksine ilişkin çeyreklik veriler }\end{array}$ & $\begin{array}{ll}\text { ARDL Sinır Testi } \\
\text { ve } \quad \text { Hata } \\
\text { Düzeltme } \\
\text { Modeli }\end{array}$ & $\begin{array}{l}\text { Uzun ve kısa dönemde tüm hisseler endeksi ve döviz } \\
\text { kurunun gayrimenkul yatırım ortaklıklarının temettü } \\
\text { getirilerini pozitif yönde etkilediği, kisa dönemde } \\
\text { piyasa kapitalizasyonunun ise negatif yönde } \\
\text { etkilediği belirlenmiştir. }\end{array}$ \\
\hline
\end{tabular}

Literatürde yer alan çalışmalar incelendiğinde farklı piyasalar için konut fiyat endeksi, faiz oranları ve enflasyon oranlarının GYO hisse senedi fiyat ve getirileri üzerindeki etkisine ilişkin farklı bulgulara ulaşıldığı görülmektedir. Türkiye için ise GYO hisse fiyatı ve getirilerine etki eden faktörleri inceleyen çalışmaların sınırlı olduğuna rastlanmıştır. Bu çalışmada konut fiyat endeksi, faiz oranı ve enflasyon oranının BİST Gayrimenkul Yatırım Ortaklıkları Endeksi üzerindeki etkisi güncel bir veri seti ve literatürde yer alan Türkiye piyasası için yapılan çalışmalardan farklı bir yöntem ile incelenerek literatüre katkı sağlanacak, elde edilecek bulgular uygulayıcıların (yatırımcılar, yöneticiler vb.) karar süreçlerinde kullanabilecekleri önemli bilgiler içerecektir.

\section{Veri ve yöntem}

$\mathrm{Bu}$ çalışmada GYO hisse senedi fiyatları üzerinde etkili olan faktörler araştırılmıştır. Bu amaç doğrultusunda GYO hisse senedi fiyatlarını birlikte değerlendirmek amaciyla BİST Gayrimenkul Yatıım Ortaklıkları Endeksinden faydalanılmıştır. GYO'ların portföylerinde ağırlıklı olarak gayrimenkul, gayrimenkul projeleri ve gayrimenkule dayalı haklar bulunduran şirketler olmaları nedeniyle BİST Gayrimenkul Yatırım Ortaklıkları Endeksi üzerinde etkisi olması beklenen konut fiyat endeksi, konut kredisi faiz oranları ve kira tüketici fiyat endeksi veri setine dahil edilmiş ve çalışmada kullanılan değişkenler Tablo 4'de gösterilmiştir. İlgili değişkenlere ait veriler Ocak 2010-Aralık 2020 dönemi için aylık düzeyde kullanılmıştır. İnsanlardan veya hayvanlardan veri toplamadan gerçekleştirilen analizlerden dolayı etik kurul izin belgesine gerek duyulmamıştır. 
Tablo 4. Çalışmada Kullanılan Değişkenler

\begin{tabular}{|c|c|c|c|}
\hline Sembol & Değişken & Açıklama & Kaynak \\
\hline XGMYO & $\begin{array}{lr}\text { BIST } & \text { Gayrimenkul } \\
\text { Yatırım } & \text { Ortaklıkları } \\
\text { Endeksi } & \\
\end{array}$ & $\begin{array}{l}\text { BİST Gayrimenkul Yatırım Ortaklıkları Endeksinin ayın } \\
\text { son iş günündeki kapanış değerinin logaritması }\end{array}$ & Borsa İstanbul \\
\hline KFE & Konut Fiyat Endeksi & $\begin{array}{l}\text { Türkiye genelini temsil etmek üzere, konutların } \\
\text { gözlemlenebilen özelliklerine bağlı kalite etkisinden } \\
\text { arındırılmış fiyat değişimlerini izlemek amacıyla, } \\
\text { hedonik regresyon yöntemi kullanılarak oluşturulan } \\
\text { fiyat endeksinin }(2017=100) \text { logaritması }\end{array}$ & $\begin{array}{l}\text { Türkiye Cumhuriyet } \\
\text { Merkez Bankası }\end{array}$ \\
\hline KTÜFE & $\begin{array}{l}\text { Kira Tüketici Fiyat } \\
\text { Endeksi }\end{array}$ & $\begin{array}{l}\text { Özel kapsamlı tüketici fiyatları endeksi göstergelerinde } \\
\text { yer alan kira tüketici fiyat endeksinin }(2003=100) \\
\text { logaritması }\end{array}$ & $\begin{array}{l}\text { Türkiye } \\
\text { Kurumu }\end{array}$ \\
\hline FAIZ & $\begin{array}{l}\text { Konut Kredisi Faiz } \\
\text { Oranları }\end{array}$ & $\begin{array}{l}\text { Bankalarca TL Üzerinden Açılan Konut Kredilerine } \\
\text { Uygulanan Ağırlıklı Ortalama Faiz Oranları (Akım } \\
\text { Veriler,\%) }\end{array}$ & $\begin{array}{l}\text { Türkiye Cumhuriyet } \\
\text { Merkez Bankası }\end{array}$ \\
\hline
\end{tabular}

Çalısmada konut fiyat endeksi, kira tüketici fiyat endeksi ve konut kredisi faiz oranlarının BíST Gayrimenkul Yatırım Ortaklıkları Endeksi üzerindeki etkisi Pesaran, Shin ve Smith (2001) tarafından geliştirilen ARDL sınır testi ile incelenmiştir. ARDL sınır testi yaklaşımı, değişkenlerin I(0) ve/veya I(1) olması durumunda kullanılabilmesi, küçük örneklemlerde eşbütünleşme ilişkisini belirlemek için istatistiksel olarak daha anlamlı bir yaklaşım olması, değişkenlerin farklı optimal gecikmelere sahip olmasına izin vermesi ve uzun vadeli ilişkileri tahmin etmede tek bir indirgenmiş form denklemini kullanması gibi üstünlükleriyle Engle ve Granger (1987), Johansen (1988) ve Johansen ve Juselius (1990) gibi geleneksel eşbütünleşme testlerinden farklılaşmaktadır (Öztürk ve Acaravcl, 2010). ARDL yaklaşımı, hem $\mathrm{I}(1)$ hem de $\mathrm{I}(0)$ seriler ile eşbütünleşme vektörünün tahminine izin verirken, serilerden herhangi birinin I(2) olmadığının belirlenmesi önemlidir (De Vita ve Abbott, 2004). Çalışmada serilerin hangi mertebe durağan oldukları Phillips-Perron (PP) (1988), Kwiatkowski Phillips, Schmidt ve Shin (KPSS) (1992) ve Elliott, Rothenberg ve Stock (1996) DF-GLS birim kök testleri ile araştırılmıştır.

ARDL sınır testi yaklaşımında iki aşama vardır. İlk aşamada, modeldeki değişkenler arasındaki eşbütünleşme ilişkisi, sınırsız hata düzeltme modeli (UECM) ile incelenmektedir. Değiş̧kenler arasında eşbütünleşme ilişkisi varsa ikinci aşamada modelin uzun ve kısa dönem katsayıları tahmin edilmektedir (Akalin, Özbek ve Çifçi, 2018). Bu çalışmada kullanılacak ARDL sınır testi ile eşbütünleşmeyi test eden sınırsız ECM için Eşitlik (1) kullanılacaktır, Eşitlik (1) için değişkenler arasında uzun dönemli bir ilişki olmadığı şeklindeki boş hipotez $(\mathrm{H} 0)$ reddedilirse yani eşbütünleşme tespit edilirse, bağımsız değişkenlerin BísT Gayrimenkul Yatırım Ortaklıkları Endeksi üzerindeki etkisinin belirlenmesinde Eşitlik (2) ve Eşitlik (3) kullanılacaktır.

$$
\begin{aligned}
& \Delta X G M Y O_{t}=y_{0}+\sum_{i=1}^{a} y_{1 i} \Delta X G M Y O_{t-i}+\sum_{i=0}^{b} y_{2 i} \Delta K F E_{t-i}+\sum_{i=0}^{c} y_{3 i} \Delta K T U ̈ F E_{t-i}+ \\
& \sum_{i=0}^{d} y_{4 i} \Delta F A \mathrm{I} Z_{t-i}+\alpha_{1} X G M Y O_{t-1}+\alpha_{2} K F E_{t-1}+\alpha_{3} K T \ddot{U} F E_{t-1}+\alpha_{4} F A \dot{\mathrm{I}} Z_{t-1}+\epsilon_{t} \\
& X G M Y O_{t}=y_{0}+\sum_{i=1}^{a} y_{1 i} X G M Y O_{t-i}+\sum_{i=0}^{b} y_{2 i} K F E_{t-i}+\sum_{i=0}^{c} y_{3 i} K T \mathrm{U} F E_{t-i}+\sum_{i=0}^{d} y_{4 i} F A \dot{\mathrm{I}} Z_{t-i}+\epsilon_{t} \\
& \Delta X G M Y O_{t}=y_{0}+\sum_{i=1}^{a} y_{1 i} \Delta X G M Y O_{t-i}+\sum_{i=0}^{b} y_{2 i} \Delta K F E_{t-i}+\sum_{i=0}^{c} y_{3 i} \Delta K T \ddot{\mathrm{U}} F E_{t-i}+\sum_{i=0}^{d} y_{4 i} \Delta F A \dot{\mathrm{I}} Z_{t-i}+ \\
& \psi E C T_{t-1}+\epsilon_{t}
\end{aligned}
$$

\section{Bulgular}

Çalışmada ARDL sınır testi kullanılacak olup değişkenlerin düzeyde ve/veya birinci farkta durağan olması gerekmektedir. Değişkenlerin birim kök içerip içermediği Phillips-Perron (PP) (1988), Kwiatkowski Phillips, Schmidt ve Shin (KPSS) (1992) ve Elliott, Rothenberg ve Stock (1996) DF-GLS birim kök testleri ile araştırılmış ve sonuçlar Tablo 5, Tablo 6 ve Tablo 7'de sunulmuştur.

XGMYO değişkeni için PP Birim Kök Testinin serinin durağan olmadığı şeklindeki boş hipotezi birinci farkta sabitli ve sabitli-trendli modellerde reddedilmiş ve $\% 1$ anlamlllık düzeyinde serinin birinci farkta durağan olduğu belirlenmiş̧ir. KPSS Birim Kök Testi için sabitli ve sabitli-trendli modellerde kritik değerden küçük olan LM-istatistikleri serinin durağan olduğunu ifade eden boş hipotezin reddedilememesini ve XGMYO değişkeninin düzeyde ve birinci farkta birim kök içermediğine karar verilmesini sağlamıştır. DF-GLS Birim Kök Testiyle de XGMYO değişkeninin sabitli modelde \%10 anlamlılık düzeyinde, sabitli-trendli modelle $\% 1$ anlamlılık düzeyinde birinci farkta durağan olduğu belirlenmiştir. Her üç test sonucuna göre de XGMYO değişkeninin birinci farkta durağan olduğu belirlenmiştir. KFE değişkeninin PP birim kök testinin sabitli ve sabitli-trendli modellerine göre \%1 
anlamlılık düzeyinde birinci farkta durağan olduğu, KPSS birim kök testinin sabitli modeline göre birinci farkta ve sabitli-trendli modeline göre düzeyde ve birinci farkta durağan olduğu, DF-GLS Birim Kök Testinin sabitli modeline göre $\% 1$ ve sabitli-trendli modeline göre $\% 5$ anlamlılık düzeyinde birinci farkta durağan olduğu belirlenmiştir. KTÜFE değişkeninin PP birim kök testinin her iki modeline göre de birinci farkta durağan olduğu \%1 anlamlılık düzeyinde belirlenmiştir. KPSS birim kök testine göre düzeyde ve birinci farkta birim kök içeren KTÜFE değişkeninin, DF-GLS Birim Kök Testinin sabitli modeline göre $\% 5$ ve sabitli-trendli modeline göre $\% 1$ anlamlılık düzeyinde birinci farkta durağan olduğu belirlenmiştir. Uygulanan üç testten ikisine göre birinci farkta durağan olan KTÜFE değişkeninin birinci farkta durağan olduğu değerlendirilmiştir. FAİZ değişkeninin ise PP Birim Kök Testine göre birinci farkta, KPSS ve DF-GLS Birim Kök Testlerine göre düzeyde ve birinci farkta durağan olduğu belirlenmiştir. Çalışmada kullanılan dört değişkenin de düzeyde veya birinci farkta durağan olduğu, ARDL testi için gerekli I(0) ve/veya I(1) olma gerekliliğini taşıdıkları sonucuna ulaşılmıştır.

Tablo 5. Phillips-Perron (PP) Birim Kök Testi Sonuçları

\begin{tabular}{|c|c|c|c|c|}
\hline \multirow[b]{2}{*}{ Değişkenler } & \multicolumn{2}{|c|}{ Düzeyde } & \multicolumn{2}{|c|}{ Birinci Farkta } \\
\hline & Sabitli & $\begin{array}{l}\text { Sabitli- } \\
\text { Trendli }\end{array}$ & Sabitli & $\begin{array}{l}\text { Sabitli- } \\
\text { Trendli }\end{array}$ \\
\hline XGMYO & $\begin{array}{l}-1.8259 \\
(0.3666)\end{array}$ & $\begin{array}{c}-2.0493 \\
(0.5686)\end{array}$ & $\begin{array}{c}-11.0666^{\mathrm{a}} \\
(0.0000)\end{array}$ & $\begin{array}{r}-11.0506^{a} \\
(0.0000)\end{array}$ \\
\hline KFE & $\begin{array}{c}1.5169 \\
(0.9993)\end{array}$ & $\begin{array}{l}-1.5418 \\
(0.8101)\end{array}$ & $\begin{array}{l}-6.6081^{a} \\
(0.0000)\end{array}$ & $\begin{array}{l}-6.9322^{a} \\
(0.0000)\end{array}$ \\
\hline KTÜFE & $\begin{array}{c}7.2967 \\
(1.0000)\end{array}$ & $\begin{array}{l}-3.1918^{c} \\
(0.0906)\end{array}$ & $\begin{array}{c}-5.2417 \mathrm{a} \\
(0.0000)\end{array}$ & $\begin{array}{l}-7.8754^{a} \\
(0.0000)\end{array}$ \\
\hline FAİZ & $\begin{array}{l}-2.1958 \\
(0.2089)\end{array}$ & $\begin{array}{l}-2.6653 \\
(0.2528)\end{array}$ & $\begin{array}{l}-5.5360^{a} \\
(0.0000)\end{array}$ & $\begin{array}{l}-5.5351^{a} \\
(0.0000)\end{array}$ \\
\hline
\end{tabular}

${ }^{a}$, ${ }^{b}$ ve ${ }^{c}$ sırasıyla $\% 1, \% 5$ ve \%10 istatistiksel anlamlılık düzeyini ifade etmektedir. Parantez içerisindeki değerler t istatistiği olasılık değerleridir.

Tablo 6. KPSS Birim Kök Testi Sonuçları

\begin{tabular}{llccc} 
& & Düzeyde & Birinci Farkta & Kritik Değerler \\
\cline { 3 - 4 } & Dę̆̈işkenler & LM-istatistĭ̆ $i$ & LM-istatistiği & \\
\hline Sabitli Model & XGMYO & 0.1683 & 0.1291 & $\% 1 \rightarrow 0.7390$ \\
& KFE & 1.4279 & 0.2670 & $\% 5 \rightarrow 0.4630$ \\
& KTüFE & 1.4121 & 1.3777 & $\% 10 \rightarrow 0.3470$ \\
\hline SAbitli- Trendli & XGMYO & 0.4898 & 0.0421 & $\% 1 \rightarrow 0.2160$ \\
Model & KFE & 0.0678 & 0.0952 & $\% 5 \rightarrow 0.1460$ \\
& KTÜFE & 0.1017 & 0.1140 & $\% 10 \rightarrow 0.1190$ \\
\hline
\end{tabular}

Tablo 7. DF-GLS Birim Kök Testi Sonuçları

\begin{tabular}{|c|c|c|c|c|c|c|c|c|c|}
\hline & & \multicolumn{4}{|c|}{ Düzeyde } & \multicolumn{4}{|c|}{ Birinci Farkta } \\
\hline & Değiş̧kenler & t-istatistiği & $\begin{array}{c}\text { \%1 Kritik } \\
\text { Değer }\end{array}$ & $\begin{array}{c}\% 5 \text { Kritik } \\
\text { Değer }\end{array}$ & $\begin{array}{c}\% 10 \text { Kritik } \\
\text { Değer }\end{array}$ & $t$-istatistiği & $\begin{array}{c}\text { \%1 Kritik } \\
\text { Değer }\end{array}$ & $\begin{array}{c}\text { \%5 Kritik } \\
\text { Değer }\end{array}$ & $\begin{array}{c}\text { \%10 Kritik } \\
\text { Değer }\end{array}$ \\
\hline Sabitli & XGMYO & -1.0697 & -2.5827 & -1.9433 & -1.6151 & -1.8129 & -2.5834 & -1.9433 & -1.6150 \\
\hline \multirow[t]{3}{*}{ Model } & $K F E$ & 1.7433 & -2.5832 & -1.9433 & -1.6151 & -2.6784 & -2.5832 & -1.9433 & -1.6151 \\
\hline & KTÜFE & 0.1192 & -2.5836 & -1.9434 & -1.6150 & -2.4200 & -2.5830 & -1.9433 & -1.6151 \\
\hline & FAİZ & -3.1677 & -2.5829 & -1.9433 & -1.6151 & -7.0337 & -2.5830 & -1.9433 & -1.6151 \\
\hline Sabitli- & XGMYO & -2.1695 & -3.5428 & -2.9990 & -2.7090 & -9.7699 & -3.5440 & -3.0000 & -2.7100 \\
\hline Trendli & $K F E$ & -1.8878 & -3.5464 & -3.0020 & -2.7120 & -3.4804 & -3.5464 & -3.0020 & -2.7120 \\
\hline \multirow[t]{2}{*}{ Model } & KTÜFE & 0.0148 & -3.5440 & -3.0000 & -2.7100 & -7.7270 & -3.5440 & -3.0000 & -2.7100 \\
\hline & FAİZ & -3.7935 & -3.5440 & -3.0000 & -2.7100 & -6.8632 & -3.5452 & -3.0010 & -2.7110 \\
\hline
\end{tabular}

ARDL sınır testi için öncelikle uygun gecikme uzunluğunun belirlenmesi gerekmektedir. Uygun modelin seçilmesi için değişkenlerin farklı gecikme kombinasyonları ile sınanarak, bilgi kriterlerine göre en düşük değeri veren model belirlenir (Esen, Yıldırım ve Kostakoğlu, 2012). Bu çalışmada Akaike Bilgi Kriterine (AIC) göre ARDL $(12,12,11,9)$ modeli uygun model olarak seçilmiştir (Şekil 1). 
Akaike Information Criteria (top 20 models)

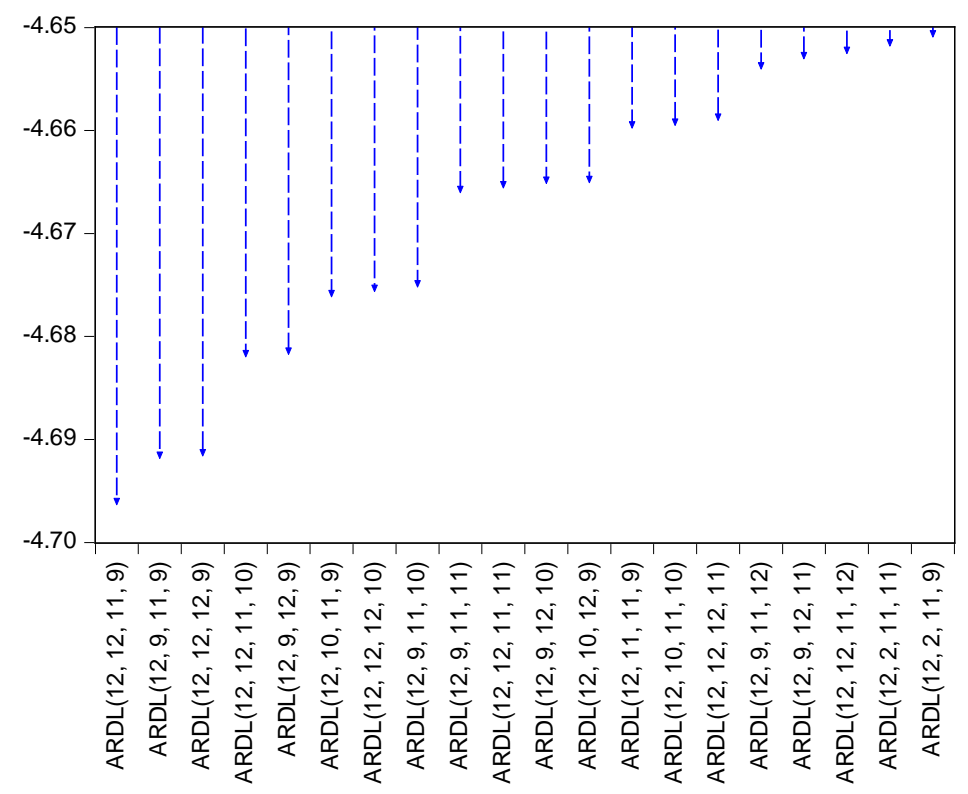

Şekil 1. Sınır Testi için Uygun Gecikme Uzunluğunun Seçimi

Belirlenen ARDL $(12,12,11,9)$ modeli için sınır testi sonuçları Tablo 8' de yer almaktadır. F-istatistiğinin \%1 anlamlılık düzeyinde üst sınır kritik değerinden büyük olduğu belirlenmiştir. Bu nedenle değişkenler arasında eşbütünleşme olmadığını belirten boş hipotez $\left(\mathrm{H}_{0}\right)$ reddedilmiş, \%1 anlamlılık düzeyinde değişkenler arasında eşbütünleşme olduğunu belirten alternatif hipotez $\left(\mathrm{H}_{1}\right)$ kabul edilmiştir.

Tablo 8. ARDL Sınır Testi Sonuçları

\begin{tabular}{cc|c|cc|cc}
\hline \multirow{2}{*}{ Model } & \multirow{2}{*}{$\begin{array}{c}\text { F- } \\
\text { istatistiği }\end{array}$} & Olasılık & \multicolumn{2}{|c}{ F-istatistiği için kritik değerlera } & \multicolumn{2}{|c}{ F-istatistiği için kritik değerler ${ }^{\mathrm{b}}$} \\
\cline { 3 - 7 } & \multirow{3}{*}{$(12,12,11,9)$} & $10 \%$ & $\mathrm{I}(0)$ & $\mathrm{I}(1)$ & $\mathrm{I}(0)$ & $\mathrm{I}(1)$ \\
& \multirow{3}{*}{7.1331} & $5 \%$ & 2.37 & 3.20 & 2.474 & 3.312 \\
& & $1 \%$ & 3.65 & 4.67 & 2.92 & 3.838 \\
\hline
\end{tabular}

a Pesaran, Shin ve Smith (2001) tarafından $\mathrm{T}=1000$ ve $\mathrm{k}=3$ için belirlenen kritik değerlerdir.

b Narayan (2005) tarafından Case II: $\mathrm{T}=30$ ve $\mathrm{k}=5$ için kısıtlı sabit ve trendsiz model için önerilen kritik değerlerdir.

Optimal gecikme uzunluğunun seçiminde Akaike bilgi kriterleri (AIC) kullanılmış ve her değişken için maksimum gecikme uzunluğu 12 olarak belirlenmiştir.

Değişkenler arasında eşbütünleşme bulunduğu belirlendikten sonra değişkenler için uzun dönemli katsayı tahminleri yapılarak sonuçlar Tablo 9'te gösterilmiştir. Elde edilen sonuçlar KFE değişkeninin \%1 istatistiksel anlamlılık düzeyinde XGMYO değişkenini uzun dönemde pozitif olarak etkilediğini ortaya koymuştur. Konut fiyat endeksindeki \%1'lik artışın BIST Gayrimenkul Yatırım Ortaklıklarını endeksini yaklaşık \%2,61 artırdığı belirlenmiştir. Sırasıyla \%1 ve \%10 anlamlılık düzeylerinde anlamlı olan KTÜFE ve FAİZ değişkenlerindeki artışın ise XGMYO değişkenini azalttığı tespit edilmiştir. Kira tüketici fiyat endeksindeki \%1'lik bir artış BíST Gayrimenkul Yatırım Ortaklıklarını endeksini yaklaşık \%2.16 düşürürken, konut kredisi faiz oranlarındaki 100 baz puanlık bir artışın BİST Gayrimenkul Yatırım Ortaklıklarını endeksini yaklaşık \%0.006 düşürdüğü belirlenmiştir. Tanı testleri de modeldeki hata terimlerinin normal dağıldığını (Jarque-Bera), değişen varyans (Breusch Pagan Godfrey Testi) ve otokorelasyon (Breusch-Godfrey Seri Korelasyon LM Testi) sorununun olmadığını ve modelin iyi tanımlandığını göstermektedir (Ramsey RESET Test). Ayrıca tahmin edilen model için parametre kararlılığı CUSUM ve CUSUMSQ testleri ile incelenmiştir. Test sonuçları Şekil 2'de gösterilmiştir. Şekil 2 incelendiğinde, özyinelemeli kalıntıların kümülatif toplamını (CUSUM) ve özyinelemeli kalıntıların karelerinin kümülatif toplamını (CUSUMSQ) gösteren çizimlerin sınırlar içinde (\%95 güven aralığında) olması, tahminlerin kararlılı̆ııı doğrulamaktadır. 
Tablo 9. Uzun Dönem Katsayıları Tahmin Sonuçları

\begin{tabular}{|c|c|c|c|}
\hline \multicolumn{4}{|c|}{ Bağımlı Değişken: XGMYO } \\
\hline Bağımsız Değişken & Katsayı & t-istatistiği & Olasılık \\
\hline KFE & 2.6053 & 5.5402 & 0.0000 \\
\hline KTÜFE & -2.1594 & -4.3625 & 0.0000 \\
\hline FAİZ & -0.0058 & -1.7584 & 0.0829 \\
\hline $\mathrm{C}$ & 3.8009 & 6.9425 & 0.0000 \\
\hline \multicolumn{4}{|c|}{ Tanısal (Diagnostik) Testler } \\
\hline \multicolumn{3}{|c|}{ İstatistik } & Olasılık \\
\hline Jarque-Bera & 2.3481 & \multicolumn{2}{|r|}{0.3091} \\
\hline Breusch-Godfrey Serial & 0.4022 & \multicolumn{2}{|r|}{0.6704} \\
\hline Breusch Pagan Godfrey Test & 0.7162 & \multicolumn{2}{|r|}{0.8883} \\
\hline Ramsey RESET Test & 1.7001 & \multicolumn{2}{|r|}{0.1965} \\
\hline
\end{tabular}
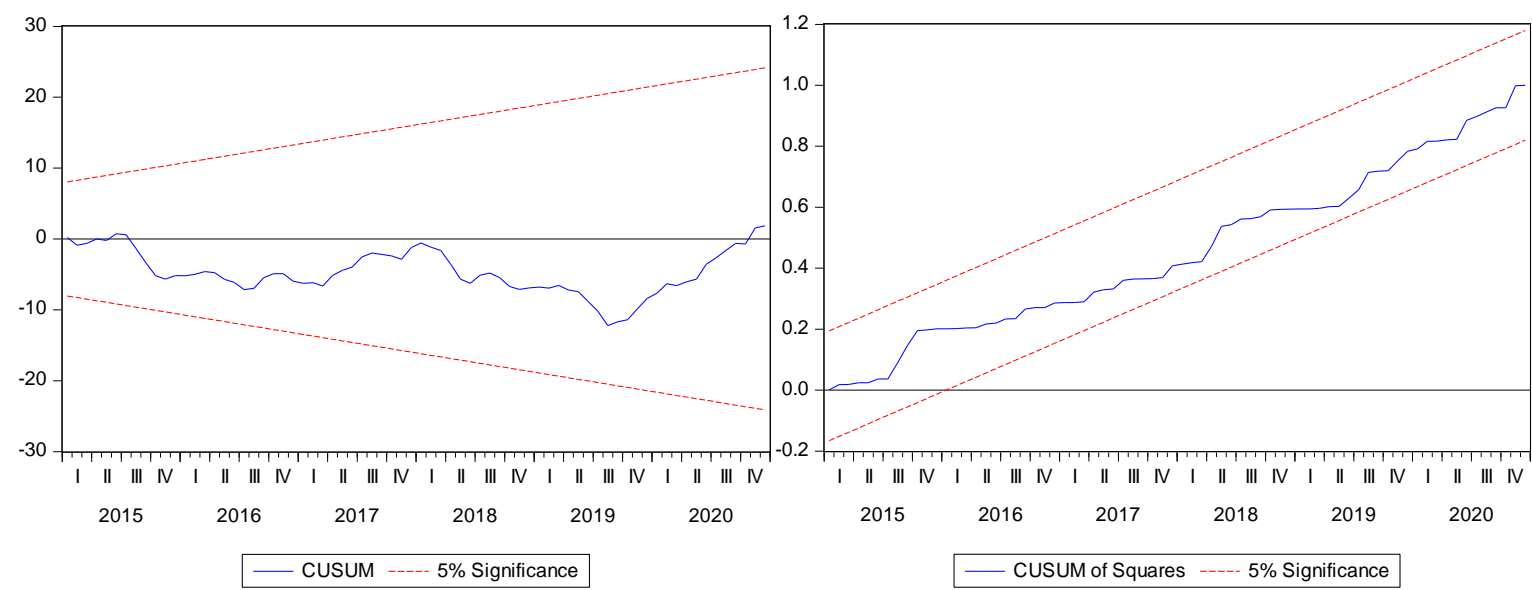

Şekil 2. CUSUM ve CUSUMSQ Testleri

Hata düzeltme modeline dayanan değişkenlerin kısa dönem katsayı tahminleri Tablo 10'da sunulmuştur. Hata teriminin bir dönem gecikmeli değeri $(\operatorname{ECM}(-1))$, -1 ile 0 arasında bir değere sahip ve istatistiksel olarak anlamlıdır. Bu durum kısa dönemde meydana gelecek bir şokun etkilerinin ortadan kalkacağını, uzun dönem dengeye yaklaşılacağını ifade etmektedir. ECM(-1) katsayısının 0.51 olması, meydana gelen bir şoktan sonra uzun dönem dengesinde meydana gelen bir sapmanın bir ay içerisinde yaklaşık \%51'inin düzelerek uzun dönemli dengeye yaklaşacağını, yaklaşık 2 ayda uzun dönem dengesinin sağlanacağını ifade etmektedir. 
Tablo 10. ARDL Hata Düzeltme Modeli Sonuçları

\begin{tabular}{|c|c|c|c|}
\hline \multicolumn{4}{|c|}{ Bağımlı Değişken: XGMYO } \\
\hline Değişken & Katsay1 & t-istatistiği & Olasılık \\
\hline $\mathrm{D}(\mathrm{XGMYO}(-1))$ & 0.1144 & 1.2216 & 0.2258 \\
\hline $\mathrm{D}(\mathrm{XGMYO}(-2))$ & 0.1631 & 1.7108 & 0.0914 \\
\hline $\mathrm{D}(\mathrm{XGMYO}(-3))$ & 0.1524 & 1.5968 & 0.1147 \\
\hline $\mathrm{D}(\mathrm{XGMYO}(-4))$ & 0.1009 & 1.1317 & 0.2615 \\
\hline $\mathrm{D}(\mathrm{XGMYO}(-5))$ & 0.2517 & 2.9641 & 0.0041 \\
\hline $\mathrm{D}(\mathrm{XGMYO}(-6))$ & 0.3246 & 4.0836 & 0.0001 \\
\hline $\mathrm{D}(\mathrm{XGMYO}(-7))$ & -0.0289 & -0.3439 & 0.7319 \\
\hline $\mathrm{D}(\mathrm{XGMYO}(-8))$ & -0.0538 & -0.6928 & 0.4906 \\
\hline $\mathrm{D}(\mathrm{XGMYO}(-9))$ & 0.1521 & 2.0046 & 0.0488 \\
\hline $\mathrm{D}(\mathrm{XGMYO}(-10))$ & 0.1548 & 2.0202 & 0.0471 \\
\hline $\mathrm{D}(\mathrm{XGMYO}(-11))$ & -0.2589 & -3.4410 & 0.0010 \\
\hline $\mathrm{D}(\mathrm{KFE})$ & 1.0000 & 0.9666 & 0.3370 \\
\hline $\mathrm{D}(\mathrm{KFE}(-1))$ & -2.1813 & -1.8489 & 0.0686 \\
\hline $\mathrm{D}(\mathrm{KFE}(-2))$ & -2.1264 & -1.7295 & 0.0880 \\
\hline $\mathrm{D}(\mathrm{KFE}(-3))$ & -1.6414 & -1.2102 & 0.2302 \\
\hline $\mathrm{D}(\mathrm{KFE}(-4))$ & 0.1419 & 0.1103 & 0.9125 \\
\hline $\mathrm{D}(\mathrm{KFE}(-5))$ & 1.9186 & 1.5925 & 0.1157 \\
\hline $\mathrm{D}(\mathrm{KFE}(-6))$ & 0.8422 & 0.6792 & 0.4992 \\
\hline $\mathrm{D}(\mathrm{KFE}(-7))$ & 0.2054 & 0.1658 & 0.8688 \\
\hline $\mathrm{D}(\mathrm{KFE}(-8))$ & -5.3201 & -3.1617 & 0.0023 \\
\hline $\mathrm{D}(\mathrm{KFE}(-9))$ & -0.2842 & -0.1602 & 0.8732 \\
\hline $\mathrm{D}(\mathrm{KFE}(-10))$ & -0.8541 & -0.4955 & 0.6218 \\
\hline $\mathrm{D}(\mathrm{KFE}(-11))$ & 3.4384 & 2.2353 & 0.0285 \\
\hline D(KTÜFE) & -8.5749 & -2.1457 & 0.0353 \\
\hline $\mathrm{D}(\mathrm{KTÜFE}(-1))$ & -10.5692 & -2.5239 & 0.0138 \\
\hline $\mathrm{D}(\mathrm{KTÜFE}(-2))$ & -9.2447 & -2.1325 & 0.0364 \\
\hline D(KTÜFE(-3)) & -14.7661 & -3.1925 & 0.0021 \\
\hline D(KTÜFE(-4)) & -2.0457 & -0.4946 & 0.6224 \\
\hline D(KTÜFE(-5)) & 5.9174 & 1.4542 & 0.1502 \\
\hline D(KTÜFE(-6)) & -2.1081 & -0.5215 & 0.6036 \\
\hline D(KTÜFE(-7)) & -13.0513 & -3.0215 & 0.0035 \\
\hline $\mathrm{D}(\mathrm{KTÜFE}(-8))$ & -12.9196 & -2.6402 & 0.0102 \\
\hline D(KTÜFE(-9)) & -14.4502 & -2.8012 & 0.0065 \\
\hline D(KTÜFE(-10)) & -19.9626 & -3.9938 & 0.0002 \\
\hline D(FAïZ) & -0.0022 & -0.8494 & 0.3985 \\
\hline D(FAİZ(-1)) & -0.0005 & -0.1677 & 0.8673 \\
\hline D(FAİZ(-2)) & 0.0035 & 1.2200 & 0.2264 \\
\hline D(FAİZ(-3)) & -0.0074 & -2.6904 & 0.0089 \\
\hline D(FAİZ(-4)) & 0.0073 & 2.9252 & 0.0046 \\
\hline D(FAİZ(-5)) & -0.0060 & -2.1207 & 0.0374 \\
\hline D(FAİZ(-6)) & 0.0025 & 0.8198 & 0.4150 \\
\hline D(FAİZ(-7)) & 0.0017 & 0.5576 & 0.5789 \\
\hline D(FAİZ(-8)) & -0.0101 & -3.7493 & 0.0004 \\
\hline $\operatorname{ECM}(-1)$ & -0.5149 & -6.1357 & 0.0000 \\
\hline
\end{tabular}

\section{Sonuç ve değerlendirme}

Yatırımcılar ve yöneticiler için hisse senedi değerine etki eden faktörlerin belirlenmesi önem taşımaktadır. Sermaye piyasalarında gerek piyasa değerleri gerek aktif büyüklükleri gerekse işlem hacimleri ile önemli bir yere sahip olan gayrimenkul yatırım ortaklıklarının hisse değerine etki eden faktörlerin belirlenmesi de uygulayıcılar için fayda sağlayacaktır.

Bu çalışmanın amacı Türkiye piyasası için gayrimenkul yatırım ortaklıklarının hisse değeri üzerinde etkisi olan faktörlerin araştırılmasıdır. Bu amaç doğrultusunda ARDL sınır testi yaklaşımı ile BİST Gayrimenkul Yatırım Ortaklıkları Endeksi ile konut fiyat endeksi, konut kredisi faiz oranları ve kira tüketici fiyat endeksi arasındaki ilişki Ocak 2010-Aralık 2020 dönemine ait aylık verilerle incelenmiştir. Birim kök testleri ile serilerin durağanlığı araştırıldıktan sonra ARDL sınır testi ile eşbütünleşme sınanmış ve eşbütünleşme belirlenmesi neticesinde uzun ve kısa dönem katsayıları tahmin edilmiştir. 
Elde edilen bulgular konut fiyat endeksinin BİST Gayrimenkul Yatırım Ortaklıkları Endeksini pozitif yönde etkilediğini göstermiştir. Uzun dönemde konut fiyat endeksindeki \%1'lik bir artış BİST Gayrimenkul Yatırım Ortaklıkları Endeksinde \%2,61'lik bir artış sağlamaktadır. Portföylerinde ağırlıklı olarak gayrimenkuller, gayrimenkul projeleri ve gayrimenkule dayalı haklar bulunan GYO'ların konut fiyat endeksindeki artıştan dolayı varlıklarının değerinin artacağı, dolayısıyla hisse senetlerinin değerinin artacağı yönündeki beklentinin gerçekleştiği görülmektedir. Kandır ve Özhan (2018) tarafından konut fiyat endeksinin BİST Gayrimenkul Yatırım Ortaklıkları Endeksi üzerinde anlamlı bir etkisi bulunmadığı belirlenmesine rağmen bu çalışmada beklentiye paralel şekilde pozitif bir etki tespit edilmiştir. Ulaşılan bu sonuç, Nishigaki (2007) tarafından ABD piyasası için ulaşılan sonuç ile tutarlıdır.

Çalışmada özel kapsamlı tüketici fiyat endeksi göstergeleri arasında yer alan kira tüketici fiyat endeksindeki artışın BİST Gayrimenkul Yatırım Ortaklıkları Endeksini negatif yönde etkilediği, kira tüketici fiyat endeksindeki \%1'lik artışın BİST Gayrimenkul Yatırım Ortaklıkları Endeksini \%2,16 düşürdüğü belirlenmiştir. Her ne kadar kira fiyat endeksindeki artış, GYO'ların portföylerinde gayrimenkullerin nominal kira getirisini artırsa da hisse değerini olumsuz etkilemektedir. Bu durum yatıımcıların nominal getiriye odaklanmadıklarını göstermektedir. Ayrıca enflasyondaki artışın tüketimi artıran, dolayısıyla tasarruf ve yatırımları azaltan etkisi de hisse senedi değerlerinin enflasyondaki artıştan olumsuz etkilenmesine neden olmaktadır. Bu çalışmada kullanılan kira tüketici fiyat endeksi yerine farklı enflasyon göstergeleri kullanılan Nishigaki (2007), Fang ve diğerleri (2016), Arora ve diğerleri (2019) ve Cohen ve Burinskas (2020) çalışmalarında elde edilen bulgular ile bu çalışmada enflasyonun etkisi için bulunan sonuçlar tutarlıdır.

Çalışmada ulaşılan bir diğer sonuç, konut kredisi faiz oranlarındaki artışın BIST Gayrimenkul Yatırım Ortaklıkları Endeksini negatif yönde etkilediğidir. Uzun dönemde TL cinsinden konut kredisi faiz oranlarındaki 100 baz puanlık artış BİST Gayrimenkul Yatırım Ortaklıkları Endeksinin \%0.0058 düşmesine neden olmaktadır. Faiz oranlarının katsayısının düşüklüğünden görüldüğü üzere etkisi sınırlı olmakla birlikte negatif ve anlamlı olduğu belirlenmiştir. Konut kredisi faiz oranlarındaki artışın gayrimenkule olan talebi sınırlandıracağı, böylelikle GYO'ların varlıklarına olan talebin ve dolayısıyla varlıkların değerinin düşeceği değerlendirildiğinde beklenen bir ilişkinin tespit edildiği söylenebilir. Elde edilen bulgular, faizin GYO hisse değerleri üzerindeki negatif etkisini tespit eden Zügül ve Şahin (2015), Fang ve diğerleri (2016) ve Khan ve Siddiqui (2019) çalışmaları ile benzerlik göstermektedir.

Elde edilen bulgular, yatırımcılar için önemli sonuçlar içermektedir. GYO hisse senetlerine yapılacak yatırımlarda konut fiyat endeksi, faiz oranları ve enflasyon oranları yatırımcılar tarafından dikkatle değerlendirilmelidir. Konut fiyatlarında artış beklenen dönemlerde GYO hisse senetlerinin değerinde artacağı, faiz oranları ve enflasyon oranlarında artış beklenen dönemlerde GYO hisse senedi değerlerinin olumsuz etkileneceği değerlendirilerek yatırımcılar tarafından karar verilmesi yatırımcıların portföy getirilerini pozitif yönde etkileyecektir. Diğer tarafından finansal olarak hissedar değerini maksimize etme amacına odaklanan yöneticilerin, GYO'ların hisse değerinin faiz oranları ve enflasyon oranındaki artıştan ve konut fiyatlarındaki azalıştan etkilenmesini önleyici politikalar geliştirmeleri finansal amaçlarına ulaşmada etkili olacaktır. Bundan sonra yapılacak çalışmalarda GYO'ların aktif büyüklük, kaldıraç oranı gibi göstergeler açısından gruplandırılması ve bu gruplar için konut fiyat endeksi, faiz oranı ve enflasyonun hisse değerleri üzerindeki etkisinin incelenmesi literatüre katkı sağlayacaktır.

\section{Hakem Değerlendirmesi / Peer-review:}

Dış bağımsız

Externally peer-reviewed

\section{Çıkar Çatışması / Conflict of interests:}

Yazar(lar) çıkar çatışması bildirmemiştir.

The author(s) has (have) no conflict of interest to declare. 
Finansal Destek / Grant Support:

Yazar bu çalışma için finansal destek almadığını beyan etmiştir.

The author declared that this study has received no financial support.

\section{Yazar Katkıları / Author Contributions:}

Fikir/Kavram/Tasarım - Idea/Concept/Design: R.K. Veri Toplama ve/veya İşleme - Data Collection and/or Processing: R.K. Analiz ve/veya Yorum - Analysis and/or Interpretation: R.K., S.Ö. Kaynak Taraması Literature Review: R.K., S. Ö. Makalenin Yazımı - Writing the Article: R.K., S.Ö. Eleştirel İnceleme - Critical Review: R.K., S.Ö. Onay - Approval: A R.K., S.Ö.

\section{Kaynakça / References}

Afşar, A. ve Karpuz, E. (2019). Makroekonomik değişkenlerle Borsa İstanbul Gayrimenkul Yatırım Ortaklıkları Endeksi arasındaki ilişki. Anadolu Üniversitesi İktisadi ve İdari Bilimler Fakültesi Dergisi, 20(1), 52-64.

Akalin, G., Özbek, R. İ. ve Çifçi, İ. (2018). Türkiye'de gelir dağılımı ve ekonomik büyüme arasındaki ilişki: ARDL sınır testi yaklaşımı. Kastamonu Üniversitesi İktisadi ve İdari Bilimler Fakültesi Dergisi, 20(4), 59-76.

Arora, P., Killins, R. ve Gangineni, P. (2019). REIT-specific and macroeconomic determinants of REIT returns: Evidence from Singapore. Accounting and Finance, 8(30), 27-42.

Aytekin, S. ve Kahraman, E. (2015). BIST gayrimenkul yatırım ortaklıkları endeksindeki (XGMYO) şirketlerin finansal etkinliklerinin veri zarflama analizi yöntemi ile değerlendirilmesi. Niğde Üniversitesi İktisadi ve İdari Bilimler Fakültesi Dergisi, 8(1), 289-301.

Chen, K. ve Tzang, D. (1988). Interest-rate sensitivity of real estate investment trusts. Journal of Real Estate Research, 3(3), 13-22.

Cohen, V. ve Burinskas, A. (2020). The evaluation of the impact of macroeconomic indicators on the performance of listed real estate companies and REITs. Ekonomika, 99(1), 79-92.

Çelik, E. ve Arslanlı, K. Y. (2020). Gayrimenkul yatırım ortalığı firmalarının piyasa değeri ve aktif karlılı̆̆ını etkileyen finansal oranların panel veri analizi yöntemiyle belirlenmesi. Muhasebe ve Finansman Dergisi, 88, 255-274.

Çelik, Ş. ve Manan, M. T. (2018). Gayrimenkul yatırım ortaklıklarının risk ile performans ilişkisi. Muhasebe ve Finans İncelemeleri Dergisi, 1(1), 60-79.

De Vita, G. ve Abbott, A. (2004). Real exchange rate volatility and US exports: an ARDL bounds testing approach. Economic Issues, 9(1), 69-78.

Elliott, G., Rothenberg, T. J. ve Stock, J. H. (1996). Efficient tests for an autoregressive unit root. Econometrica, 64, 813-836.

Engle, R. F. ve Granger, C. W. (1987). Co-integration and error correction: representation, estimation, and testing. Econometrica, 55, 251-276.

Esen, E., Yıldırım, S. ve Kostakoğlu, S. F. (2012). Feldstein-Horioka hipotezinin Türkiye ekonomisi için sınanması: ARDL modeli uygulaması. Eskişehir Osmangazi Üniversitesi İktisadi ve İdari Bilimler Dergisi, 7(1), 251-267.

European Public Real Estate Association (ERPA). (2020). EPRA Global REIT Survey 2020. Erişim adresi: https://prodapp.epra.com/media/EPRA_Global_REIT_Survey_2020_1597930925323.pdf

Ewing, B. T. ve Payne, J. E. (2005). The response of real estate investment trust returns to macroeconomic shocks. Journal of Business Research, 58(3), 293-300.

Fang, H., Chang, T. Y., Lee, Y. H. ve Chen, W. J. (2019). The impact of macroeconomic factors on the real estate investment trust index return on Japan, Singapore and China. Innovations, 13(4-1), 242-253. 
Gayrimenkul ve Gayrimenkul Yatırım Ortaklığı Derneği (GYODER). (2021). GYODER gösterge, Türkiye gayrimenkul sektörü 2020 4.çeyrek raporu. Erişim adresi: https://www.gyoder.org.tr/uploads/gyoder_gosterge/GOSTERGE-CEYREK4-2020.pdf

Gayrimenkul Yatırım Ortaklıklarına İlişkin Esaslar Tebliği (2013, 28 Mayıs). Resmi Gazete (Sayı: 28660). Erişim adresi: https:/ /www.resmigazete.gov.tr/eskiler/2013/05/20130528-14.htm

Hoesli, M. ve Oikarinen, E. (2012). Are REITs real estate? Evidence from international sector level data. Journal of International Money and Finance, 31(7), 1823-1850.

Johansen, S. (1988). Statistical analysis of cointegration vectors. Journal of economic dynamics and control, 12, 231-254.

Johansen, S. ve Juselius, K. (1990). Maximum likelihood estimation and inference on cointegration with appucations to the demand for money. Oxford Bulletin of Economics and statistics, 52(2), 169-210.

Kandır, S. Y. ve Özhan, E. (2018). Gayrimenkul yatırım ortaklığı pay getirilerini etkileyen faktörlerin araştırılması. BDDK Bankacılık ve Finansal Piyasalar Dergisi, 12(2), 31-45.

Karakaya, A. (2017). Türkiye'deki gayrimenkul yatırım ortaklıklarının hisse senedi değeri ve süper etkinliği arasındaki ilişki. Anadolu İktisat ve İşletme Dergisi, 1(1), 1-17.

Khan, S. ve Siddiqui, D. A. (2019). Factor affecting the performance of REITs: An evidence from different markets. Erişim adresi: https:// ssrn.com/abstract=3397481

Kırdök, F. E. (2012). Dynamic relationship between macroeconomic variables and returns on Turkish real estate investment trusts (Yüksek lisans tezi, Bilkent Üniversitesi, Ankara). Erişim adresi: http://repository.bilkent.edu.tr/handle/11693/15793

Münyas, T. (2018). Gayrimenkul yatırım ortaklıklarının finansal etkinliklerinin veri zarflama analizi yöntemi ile değerlendirilmesi. Journal of Life Economics, 5(4), 111-126.

Narayan, P. K. (2005). The saving and investment nexus for China: Evidence from cointegration tests. Applied Economics, 37, 1979-1790.

Nishigaki, H. (2007). An analysis of the relationship between US REIT returns. Economics Bulletin, 13(1), 1-7.

Olanrele, O. O., Fateye, O. B., Adegunle, T. O., Ajayi, C. A., Said, R. ve Baaki, K. (2021). Causal effects of macroeconomic predictors on real estate investment trust's (REIT's) performance in Nigeria. Pacific Rim Property Research Journal, Çevrimiçi ön yayın. doi: 10.1080/14445921.2020.1857498

Özkan, A. (2018). The impact of macroeconomic variables on Turkish real estate investment trusts (T-Reits) (Yüksek lisans tezi, Çankaya Üniversitesi, Ankara). Erişim adresi: http://earsiv.cankaya.edu.tr:8080/xmlui/handle/20.500.12416/1878

Özturk, I. ve Acaravc1, A. (2010). The causal relationship between energy consumption and GDP in Albania, Bulgaria, Hungary and Romania: Evidence from ARDL bound testing approach. Applied Energy, 87(6), 1938-1943.

Pesaran, M. H., Shin, Y. ve Smith, R. J. (2001). Bounds testing approaches to the analysis of level relationships. Journal of Applied Econometrics, 16(3), 289-326.

Sermaye Piyasası Kurulu (SPK). (2021). Gayrimenkul Yatırım Ortaklıklarına İlişkin Aylık İstatistikler. Erişim adresi: https://www.spk.gov.tr/Sayfa/Index/9/0/3

Şahin, C. (2014). Firmaya özgü değişkenlerle gayrimenkul yatırım ortaklıkları (GYO) getirisi arasındaki ilişkiyi incelemeye yönelik bir uygulama. Dumlupınar Üniversitesi Sosyal Bilimler Dergisi, 42, 11-18.

Türkmen, S. Y. (2011). İMKB' de işlem gören gayrimenkul yatırım ortaklıklarının finansal etkinliklerinin veri zarflama analizi ile değerlendirilmesi. Marmara Üniversitesi İktisadi ve İdari Bilimler Dergisi, 31(2), 273-288.

World Bank. (2021). Market capitalization of listed domestic companies. Erişim adresi: https://data.worldbank.org/indicator/CM.MKT.LCAP.CD?view=chart

Zügül, M. ve Şahin, C. (2015). Faiz oranı ve enflasyonun gayrimenkul yatırım ortaklı̆̆ı getirisi üzerindeki etkisine yönelik bir uygulama. Akademik Bakış Uluslararası Hakemli Sosyal Bilimler Dergisi, $49,147-162$. 